\title{
A Palynological Study for Coastal Mangrove Swamps in Northern Hainan Island, China : Relationship between Surface Pollen and Mangrove Vegetation
}

\author{
Limi Mao*1, Kaifa Wang*2 and Hua $\mathrm{Bi}^{* 3}$
}

\begin{abstract}
Pollen analyses of surface sediment samples collected from coastal mangrove swamps in Dongzhai and Qinglan, northern Hainan Island, China, are carried out to study the relationship between surface pollen and mangrove vegetation. Six transects (1-6) from the Dongzhai and Qinglan mangrove swamps were used to examine local plant zonation pattern along intertidal zones. Four transects $(1,2,5,6)$ were sampled for pollen analysis to examine the relationship between the sedimentary environments and the zonation of mangrove swamps in the intertidal zones. All the palynomorph types extracted from surface sediment samples were counted, including pollen, fern spores, fungal spores and unknown or indeterminate remains.

The relationship among surface pollen, mangroves and local vegetation shows close linkages. Mangrove pollen taxa were roughly arranged by vegetation zones along the intertidal flat. Rhizophora pollen is markedly abundant, while Avicennia, Ceriops and Bruguiera are moderately abundant. The surface samples contained fewer pollen grains of other common mangrove types such as Excoecaria, Kandelia, Aegiceras and Xylocarpus. Exotic (non-local) palynomorphs were also present in most samples, however the most dominant types originated from the mangrove communities. We note that in northern Hainan Island mangrove pollen shows consistent distribution with their parent plant zonation, unlike common tropical terrestrial palynofloras without strong links with their parent vegetation largely due to low their pollen production, poor preservation, or unfavorable pollination mechanisms.
\end{abstract}

Key Words : Palynology, mangrove, surface pollen, northern Hainan Island, China

\section{Introduction}

"Mangrove" is an ecological term referring to a taxonomically diverse assemblage of trees and shrubs that form dominant plant communities in tidal, saline wetlands along sheltered tropical and subtropical coasts (Blasco et al., 1996). Within a diverse array of environmental settings (river, cay, shore, etc.), the vegetation of mangrove forests grows in zones composed of different species which ag- gregate in bands parallel to the shores. Mangroves are like rainforests by the sea, with high productivity and biodiversity on intertidal mudflats that form a linkage between terrestrial and marine environments. Mangroves provide many ecological and economic benefits to human, and also support and enhance coastal fisheries. The mangrove forest is a natural barrier that protects the coastline from erosion. It acts as a windbreak, prevents salinization of soils and filters pollutants. The majority

Received April 15, 2002. Accepted March 15, 2003.

*1 Department of Geosciences, Osaka City University. 3-3-138 Sugimoto, Sumiyoshi-ku, Osaka, 558-8585, Japan. Email :

*2 Department of Marine Geology \&. Geophysics, Tongji University. Shanghai, China.

*3 Department of Geography, Hainan Normal University. Hainan Province, China. 
of subtropical and tropical coastlines is dominated by mangroves, and estimates show that mangrove forests cover 15.8 million hectares, forming $0.6 \%$ of all the inland forests in the world (Peter et al., 1985). This is, however, less than half of the original mangrove forest cover, which continues to decline further at $\sim 2$ to $8 \%$ per year from human activities, such as over harvesting, freshwater diversion and conversion to other uses. Consequently, future natural and/or human related changes of mangrove ecosystems could substantially impact the economies and societies of coastal regions.

Recent studies in ecology and related fields like geography, biogeography, environmental science and coastal geomorphology in subtropics and tropics highlight the importance of the mangrove ecosystem (John, 1985 ; Tomlinson, 1986 ; Joanna, 1989, 1996 ; Woodroffe and John, 1991 ; Pieter, 1995 ; Li and Lee, 1996 ; Lin, 1999 ; Behling and Marcondes, 2001 ; Behling et al., 2001). Fossil mangrove remains, particularly pollen grains are used extensively to interpret the paleogeography and the stratigraphy of sediment cores. Mangrove pollen from sediments may indicate past warm climate and the location of paleo-shoreline during the interval of pollen deposition. First pioneered by Muller (1959, 1969, 1978), additional studies on modern and fossil pollen morphology and assemblages for mangroves have also been done (Wang et al., 1975 ; Muller and Caratini, 1977 ; Liu and Tang, 1989 ; Zhang et al., $1997 \mathrm{a}, \mathrm{b})$. Wang and Zhang (1998) identified abundant mangrove pollen in the Zhanjiang Formation that dates to the early Pleistocene, Leizhou Peninsula, northern Hainan Island. Since the early. 1990s, several palynologists have found fossil mangrove pollen along the southeastern coasts of China (Zheng, 1991, 1995, 2000 ; Zheng and $\mathrm{Li}, 2000)$. The occurrence of Sonneratia pollen from the Hanjiang Delta, southeastern China, was interpreted for climate, sea-level and coastal environmental changes (Zheng and $\mathrm{Li}, 2000$ ). In marine sediments, fossil mangrove pollen has also been well documented for the South China Sea and Southern Pacific Ocean, North Australia (John, 1985 ; Sun and Li, 1999 ; Sun et al., 1999).

Muller (1959) suggested that Rhizophora pol- len with its small size and smooth surface, can be transported farther away from the coast than other larger pollen types with sculpted surfaces. Wang et al. (1997) reported similar results with Rhizophora pollen showing small abundance in marine sediments off East China Sea. Mangrove pollen was also found in marine sediments from the South China Sea by Sun et al. (1999). These studies indicate that mangrove pollen transported by ocean currents may be redeposited. In West-Java, Indonesia, mangrove pollen, well-represented in the tropical lowland swamp of Rawa Danau, was also distributed in marine sediments from the south-eastern Indonesian waters (Sander, 2001; Sander et al., 2001). David et al. (2001) reported abundant mangrove pollen from a Late Quaternary peat formation and discussed vegetation dynamics in a lowland tropical swamp from Nee Soon, Singapore. North of Bangladesh Bay, mangrove peat developed during the regression of the Late Holocene and abundant mangrove pollen provides strong evidence for developed mangroves (Islam and Tooley, 1999). Velez et al. (2001) used sediment, diatom and pollen analysis of a core from El Caimito, southern Chocó, Central America, to show changes in mangrove vegetation during the Late Holocene. Finally, Willard et al. (2001) showed how mangrove pollen assemblages from the Everglades, Florida, may be used as a paleoenvironmental proxy to indicate coastal changes.

The study of modern analogs based on palynological data is an important tool for interpreting past environments and ecosystems. The relationship between present palynomorph assemblages and ecologies (mainly vegetation) allows better and more reliable paleoecological and paleoenvironmental reconstruction. The present study area is the coastal environments of tropical Hainan Island, southern China, where no meaningful pollen analysis for coastal mangrove swamps has been done. We established six transects $(1-6)$ to examine local mangrove zonation pattern along intertidal zones. Transect 2 is dominated by Rhizophora and Ceriops communities, even though mangrove vegetation on the landward side was reclaimed. Transect 4 is located in the 
southern part of the Dongzhai mangrove swamp, where a small creek from Sanjiang contributes frequent fresh water input. This input makes the most vegetation-rich mangrove in the study area, but rendered the pollen assemblages less representative. Tran- sect 3 receives some fresh water from the Yanfeng river (Fig. 1). We selected four transects $(1,3,5,6)$ for pollen analysis to ensure the greatest amount of local pollen deposition.
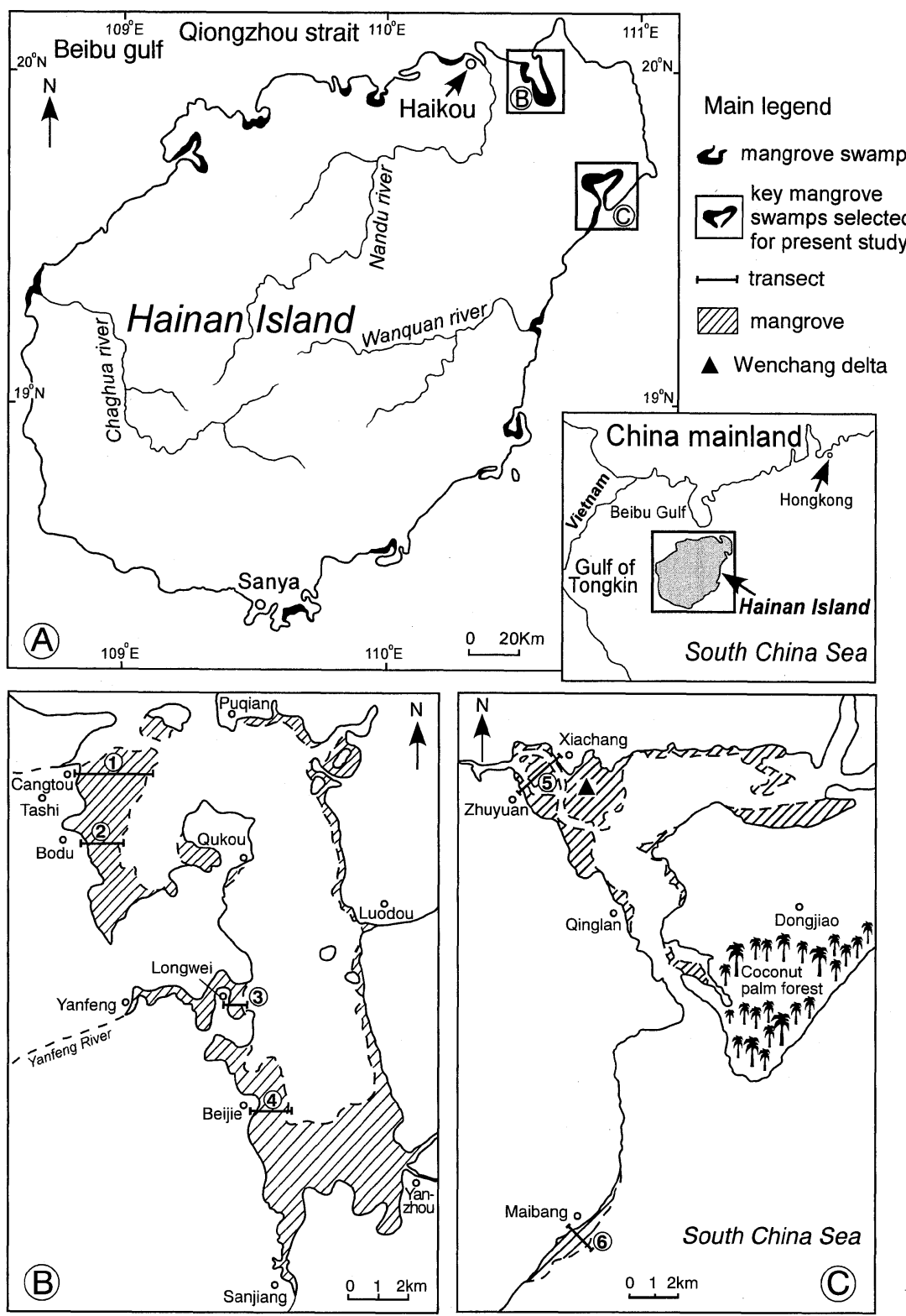

Fig. 1 Location maps of study area and mangrove swamps

Map A showing the location of Hainan Island and key mangrove swamps; Maps B and C showing mangrove swamps of Dongzhai and Qinglan and observed transects. 


\section{Study area location, climate, and vegetation}

\section{Study area location and climate}

The study area is located on the northern margin of the South China Sea. In the 1980s nature reserves for mangroves were successively established on the tropical Hainan Island of south China in order to protect mangroves from damage. Both the Dongzhai $\left(110^{\circ} 32^{\prime}-110^{\circ} 37^{\prime} \mathrm{E}, 19^{\circ} 51^{\prime}-20^{\circ} 01^{\prime} \mathrm{N}\right)$ and the Qinglan $\left(110^{\circ} 43^{\prime}-110^{\circ} 49^{\prime} \mathrm{E}, \quad 19^{\circ} 30^{\prime}-19^{\circ} 40^{\prime} \mathrm{N}\right)$ mangrove swamp lie in the northern Hainan Island (Fig. 1). We selected these two swamps for our study area because of their diversity and large sizes. The Dongzhai swamp is also a part of a tropical wetland in China, and is listed in the Wetlands International Inventory.

The climate for the coastal region of northern Hainan Island is generally tropical (warm, humid and frost-free) (Wu and Zhang, 1988). The mean annual temperature is $22-26^{\circ} \mathrm{C}$, with a mean annual precipitation of $1,600-1,800$ $\mathrm{mm}$. Drier intervals occur from December to April. The island is subjected to a modified monsoon regime, with offshore wind prevailing during the winter monsoon season and landward winds prevailing during the summer monsoon season (Hainan Geological Institute, 1992).

\section{Vegetation}

\section{1) Regional vegetation}

The vegetation in Hainan Island shows tropic biodiversities in response to a predominantly humid and warm climate, a complicated geomorphology, soil features and micro-climates throughout the Island. Regional vegetation is generally partitioned into lowland and sub-montane rain forest, mid-upper montane forest and coastal forest (Editorial Board of China Vegetation, 1995). Tropical rain forest mainly occurs in humid valleys and billabong within the southeastern Hainan Island, which is dominated by evergreen trees, such as Vatica astrotricha, Tarrietia parvifolia, Diospyros hainanensis, Leguminosae, Meliaceae, Moraceae, Melastomataceae, Araliaceae, Dipterocarpaceae, Sterculiaceae, Ebenaceae and Sapotaceae. The understory is composed of Palmae, Rubiaceae and Myrsinaceae. The trop- ical monsoon rain forest is largely distributed in the northern and western areas of the island. A yearly 5-month dry interval in the northern and western Hainan Island supports vegetation composed mainly of tropical monsoon rain forest, with a majority of arboreal evergreen trees, such as Kleinhovia hospita, Spondias pinnata, Hainania triochosperma, Apocynaceae, Anacardiaceae, Tiliaceae, Myrtaceae, Altingiaceae, Meliaceae, Euphorbiaceae. Lower layers of shrub and herb vegetation give way to Moraceae, Rubiaceae and Verbanaceae. The tropic bosks are found in the western and northwestern Hainan Island, where dry intervals occur for 8 months yearly. The tropic bosks consist of Flacourtia, Pandanus, Phoenix and Cactaceae. In the central region of Hainan Island, the topography is mountainous and hilly ; more than 6 mountains are over $1,500 \mathrm{~m}$ in altitude. Thus, various montane/upland forests are densely distributed throughout the central mountainous area. Vegetation is closely aligned with elevation in the mountains, e.g. $<500 \mathrm{~m}$ is tropical rain- and monsoon rain forest, and between 500 and $1,000 \mathrm{~m}$ is subtropical montane evergreen broad-leaved forests, as well as some tropical taxa such as Castanopsis, Pentaphylax, Lauraceae, Theaceae, and with subtropical coniferous components like Dacrydium and Podocarpus. Above $1,500 \mathrm{~m}$, evergreen coniferous trees and dwarfs, mainly of Pinus, Fagaceae, Lauraceae, Theaceae and Ericaceae dominate (Guangdong Institute of Botany, 1976).

\section{2) Coastal mangroves and associates}

Mangroves naturally occur along the southeast Chinese coasts and traverse the provinces of Hainan, Guangdong, Guangxi, Fujian and Taiwan, intermittently extending from $18^{\circ} \mathrm{N}$ to $27^{\circ} \mathrm{N}$. We documented 37 mangrove tree species, representing twenty families and twentyfive genera, with thermophilic eurytopic species being the dominant components (Lin, 2001). A decrease in species richness from 35 to 9 species, is evident from Hainan Island (18$\left.22^{\circ} \mathrm{N}\right)$ to Fujian $\left(23.5-27^{\circ} \mathrm{N}\right)$. The existing mangrove area is $\sim 17,800$ ha, accounting for slightly more than $0.1 \%$ of the world's total. Nearly two-thirds of China's mangroves have been lost during the past 40 years, largely because of 
Table 1 Mangrove species and associates in northern Hainan Island (Lin, 1999)

\begin{tabular}{|c|c|c|c|c|c|}
\hline \multirow[b]{2}{*}{ Family } & \multirow{2}{*}{$\begin{array}{l}\text { or strict mangr } \\
\text { Species }\end{array}$} & \multicolumn{4}{|c|}{ Mangrove associates } \\
\hline & & form* & Family & Species & orm* \\
\hline \multirow[t]{2}{*}{ Acanthaceae } & Acanthus ebrecteatas & $\mathrm{S}$ & Apocynaceae & Cerbera manghas & $\mathrm{T}$ \\
\hline & A. ilicifolius & $\mathrm{S}$ & Aizoaceae & Sesuvium portutacastrum & $\mathbf{S}$ \\
\hline \multirow[t]{2}{*}{ Acrostichaceae } & Acrostichum aureum & $\mathbf{F}$ & Barringtoniaceae & Barringtonia racemosa & $\mathrm{T}$ \\
\hline & A. speciosum & $\mathbf{F}$ & Bignoniaceae & Dolichandron spathacea & $\mathrm{T}$ \\
\hline \multirow[t]{2}{*}{ Combretaceae } & Lumnitzeralittorea & $\mathrm{T} / \mathrm{S}$ & Combretaceae & Conocarpus erectus & $\mathrm{T}$ \\
\hline & L. racemosa & $\mathrm{T} / \mathrm{S}$ & Compositae & Pluchea indica & $\mathrm{S}$ \\
\hline Euphorbiaceae & Excoecaria agallocha & $\mathrm{T}$ & Goodeniaceae & Scaevola hainan islandensis & $\mathrm{S}$ \\
\hline Meliaceae & Xylocarpus granatum & $\mathrm{T}$ & Hemandiaceae & Hernandia sonora & $\mathrm{T}$ \\
\hline Myrsinaceae & Aegiceras corniculatum & $\mathrm{S} / \mathrm{T}$ & Leguminosae & Pongamia pinnata & $\mathrm{T}$ \\
\hline Palmae & Nypa fruticans & $\mathbf{P}$ & Loranthaceae & Macrosolen tricolor & $\mathrm{S}$ \\
\hline \multirow[t]{8}{*}{ Rhizophoraceae } & Bruguiera cylindrica & $\mathrm{T}$ & Lythraceae & Pemphis acidula & $\mathrm{S} / \mathrm{T}$ \\
\hline & B. sexanglula & $\mathrm{T}$ & Myoporaceae & Myoporum bontioides & $\mathrm{T}$ \\
\hline & B. s. var. rhynchopetala & $\mathrm{T}$ & Malvacae & Hibiscus tilisaceus & $\mathrm{T}$ \\
\hline & B. gymnorrhiza & $\mathrm{T}$ & & Thespeaisa populnea & $\mathrm{T}$ \\
\hline & Ceriops tagal & $\mathrm{T}$ & Papilionaceae & Pongamia pinnata & $\mathbf{T}$ \\
\hline & Kandelia candel & $\mathrm{T}$ & & Derris trifoliata & $\mathrm{S}$ \\
\hline & Rhizophora apiculata & $\mathrm{T}$ & Verbenaceae & Clerodendron inerme & $\mathrm{S}$ \\
\hline & R. stylosa & $\mathrm{T}$ & & Premna obtusifolia & $\mathrm{S}$ \\
\hline Rubiaceae & Scyphiphora hydrophyllacea & $\mathrm{S}$ & & & \\
\hline \multirow[t]{5}{*}{ Sonneratiaceae } & Sonneratia caseolaris & $\mathrm{T}$ & & & \\
\hline & S. alba & $\mathrm{T}$ & & & \\
\hline & S. ovata & $\mathrm{T}$ & & & \\
\hline & S. hainan islandensis & $\mathrm{T}$ & & & \\
\hline & S. para caseolaris & $\mathrm{T}$ & & & \\
\hline Sterculiaceae & Heritiera littoralis & $\mathrm{T}$ & & & \\
\hline Verbenaceae & Avicennia marina & $\mathrm{T}$ & & & \\
\hline Total families: 12 & Total species: 26 & & Total families: 15 & Total species: 18 & \\
\hline
\end{tabular}

* Note : $\mathrm{T}=$ Tree, $\mathrm{S}=$ Shrub, $\mathrm{P}=$ Palm

conversion for rice-farming, embankment for aquaculture ponds and, recently, increasing reclamation for urban development ( $\mathrm{Li}$ and Lee, 1996).

Hainan Island has the largest mangrove distribution area and the richest species in China (Fig. 1). A total of 26 species (from 12 families) inhabit the study area (excluding one introduced species). Other mangrove types (mangrove associates) occur from fifteen families (18 species) in China (Table 1). The abundant true or strict mangrove genera are Rhizophora, Avicennia, Lumnitzera, Ceriops, Kandelia, Bruguiera and Sonneratia. Mangrove associates, such as Hibiscus and Pandanus, are abundant along the seashore, immediately adjacent to terrestrial vegetation. Typical mangrove communities were photographed in the field work, and shown in Figure 2.

\section{Materials and methods}

\section{Field methods and samples}

Our mangrove study used field observation, reference plant collections, and available photographs from existing documents (Tomlinson, 1986 ; Lin, 1999). Our work included 1) the nat- urally preserved mangrove habitats from transects 1 and 3,2) transects 2 and 4 from the Dongzhai mangrove swamp, and 3) transects 5 and 6 from the Qinglan mangrove swamp (Fig. 1). Our samples for pollen analysis were from transects 1, 3, 5, 6 and were collected within or immediate adjacent to mangrove swamps. Non-systematic surface sediment samples were collected along four transects, which consisted of superficial sediments beneath the mangroves. These samples consisted of 4 random pinches of the top $1 \sim 2 \mathrm{~cm}$ of soil/sediment over an area of $\sim 4-8 \mathrm{~m}^{2}$, and likely contain the pollen rain of the past $1-10$ years.

\section{Pollen analysis}

A total of 45 samples were treated with the standard acetolysis methods (Faegri and Iversen, 1989), using a heavy liquid (saturated $\mathrm{ZnCl}_{2}$ solution) separation. Silicone oil was used to mount pollen so that it could be turned over for identification (an approach needed to distinguish extremely similar pollen types within Rhizophoraceae). Absolute concentration of pollen and spores was determined by addition of exotic spores, using marker tablet of Lycopodium spores. We used $30 \mathrm{~g}$ of sedi- 
ment for each sample for pollen analysis. At least 300 grains of total (arboreal and nonarboreal) pollen were counted per sample for drawing the pollen diagram.

Mangrove pollen identification followed both the reference collection of the Department of Biology at Sun Yet-san University (Liu and Tang, 1989) and the Department of Marine Geology at Tongji University (Wang et al., 1975 ; Zhang et al., $1997 \mathrm{a}, \mathrm{b})$. For identification of other pollen grains, published morphological descriptions (Wang et al. 1995) were used. Per-
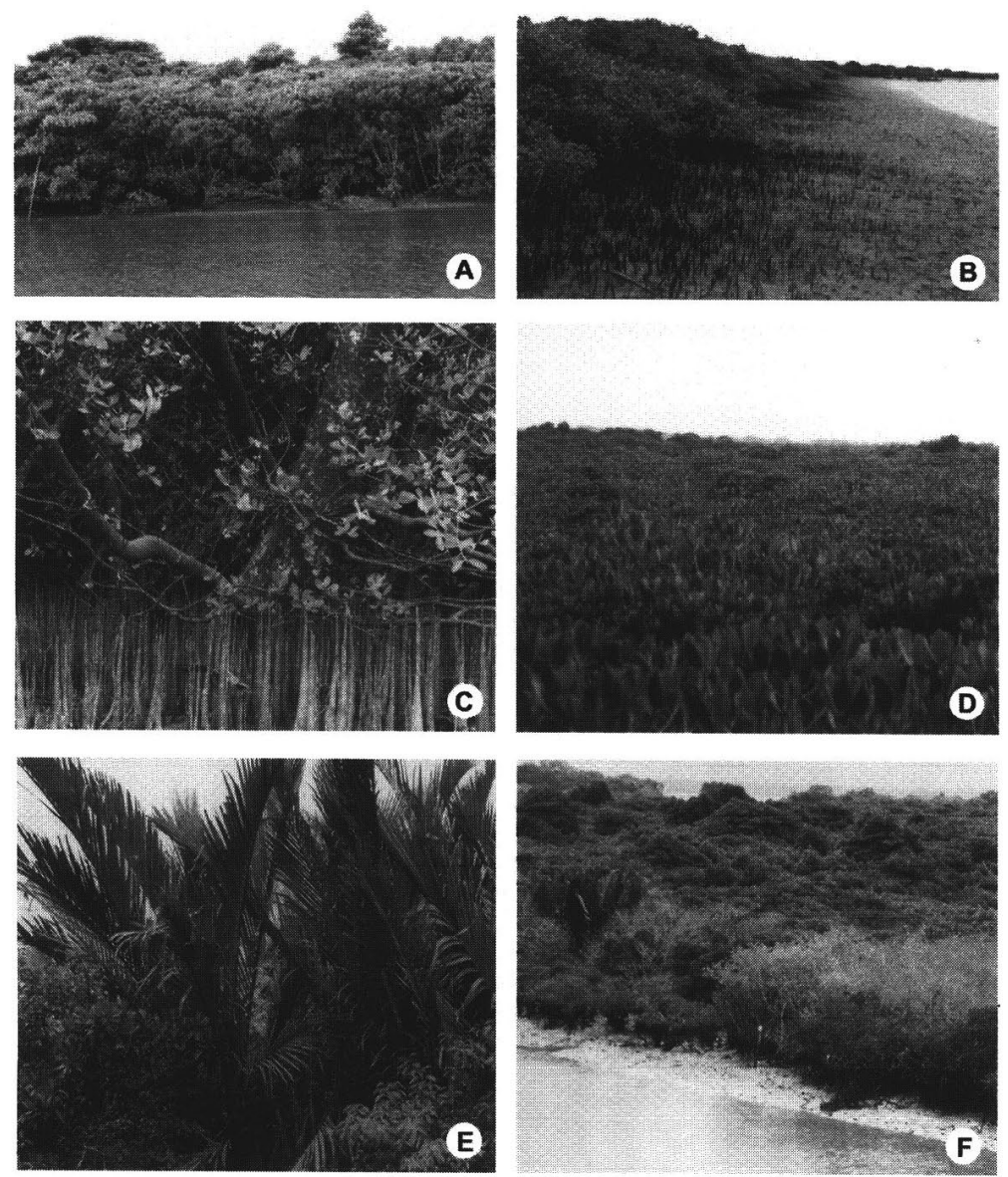

Fig. 2 Typical mangrove communities from the mangrove swamps of northern Hainan Island, China

A : Dense Kandelia candel community along the Yanfeng River of Dongzhai, B: Lagoon fringing Avicennia marina consists of pioneering genera in the north part of Dongzhai mangrove swamp, C: Pioneering genera Sonneratia ovata with bamboo-like pneumatophore from Qinglan mangrove swamp, D: Dense Rhizophora stylosa-Bruguiera gymnorrhiza community with a large area in the north part of Dongzhai mangrove swamp, E: Nypa fruticans palm in the higher tidal flat of Qinglan mangrove swamp, F : Riverine mangroves with abundant species largely due to frequent fresh water containing high nutrient sediments in the south part of Dongzhai mangrove swamp. (Photograph by Mao, L.M. in field work) 

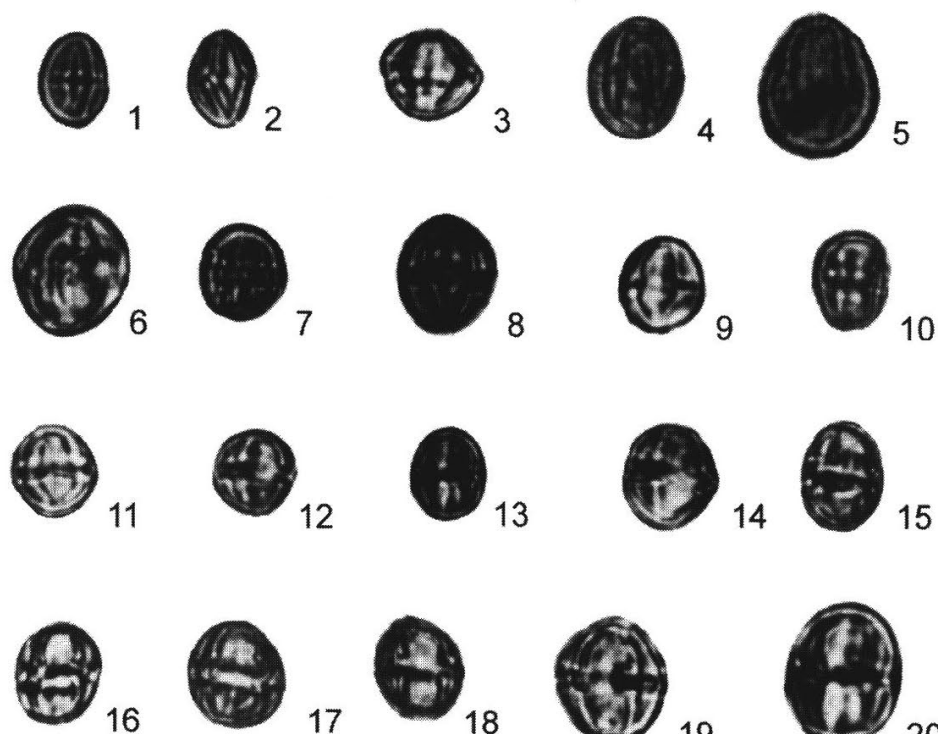

17
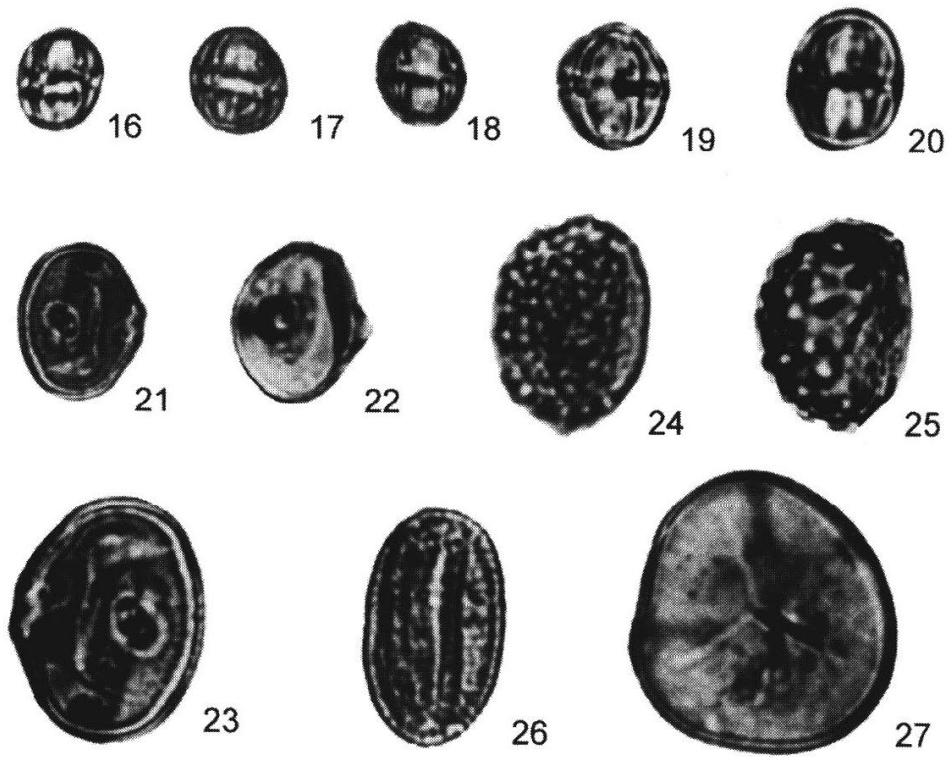

$$
\frac{20 \mu \mathrm{m}}{\text { scale for } 1-23}
$$

$$
\underset{\text { scale for } 24-27}{\stackrel{40 \mu \mathrm{m}}{\longrightarrow}}
$$

Fig. 3 Microphotographs of selected mangrove pollen and spores from the surface sediments of the mangrove swamps in northern Hainan Island, China

Note: Pollen morphology among Rhizophoraceae (particularly Kandelia candel and Bruguiera gymnorrhiza) is extremely similar under light microscope, which may cause misidentifications. According to our measurements and microscopic photographs (see 3, 9, 10), the ratio of pollen equatorial axis to polar axis of the Kandelia (subprolate-spheroidal, $22.7 \times 18.5 \mu \mathrm{m}$ in average) is larger than that of Bruguiera (oblate spheroidal-spherical, $18.4 \times 20.8 \mu \mathrm{m}$ in average); and the equatorial part of Bruguiera pollen protrudes beyond the general surface of the grain (see 3). These characteristics help distinguish pollen grains between Kandelia and Bruguiera. Kandelia pollen was also shown to be a poor producer and has lower representation (Wang et al., 1975, 1997, 1998 ; Wang and Zhang, 1998 ; Zhang et al., 1997 a, b, 1999). Lower representation of Kandelia pollen has also been reported by some palynologists (Caratini et al., 1973 ; John, 1985). 
centages of trees, shrubs and herbs for each sample were based on the sum of pollen excluding fern spores, fungal spores, aquatics and indeterminate, while percentages of spores and aquatics were based on the pollen and spores sum. Microphotography for selected mangrove pollen and spores from the study area are shown in Figure 3.

\section{Results}

\section{Modern mangrove zonation pattern}

Regardless of the overall environmental settings (river, cay, shore, etc.), mangroves assemble in diffuse zones in response to local environmental variables, such as tidal flooding, inundation frequency or salinity gradient.

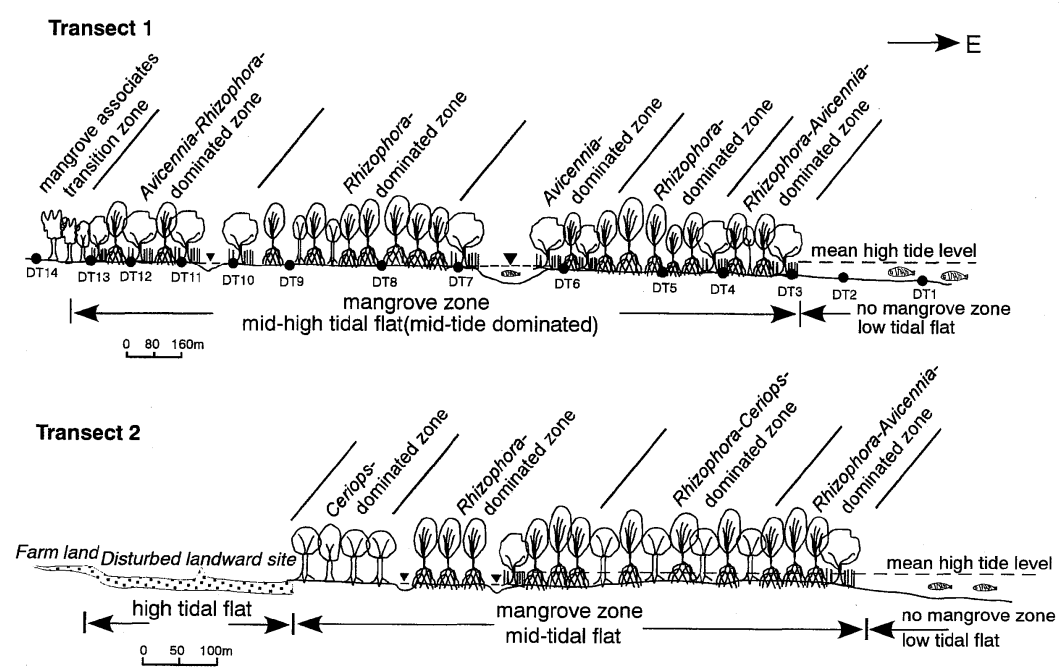

Transect 3

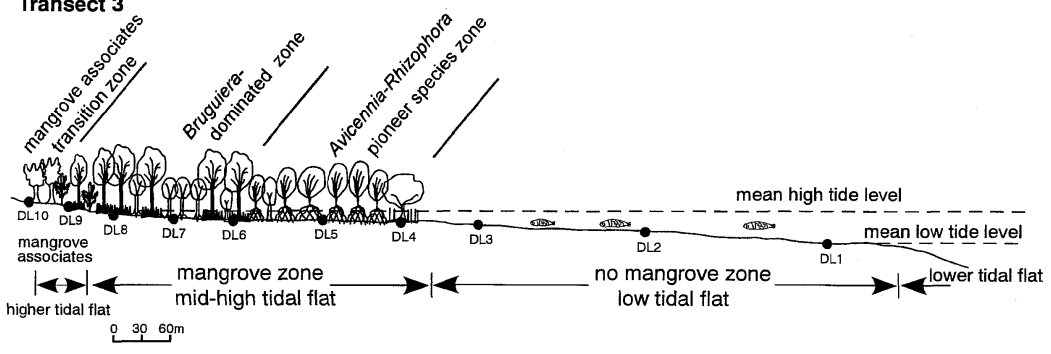

Transect 4

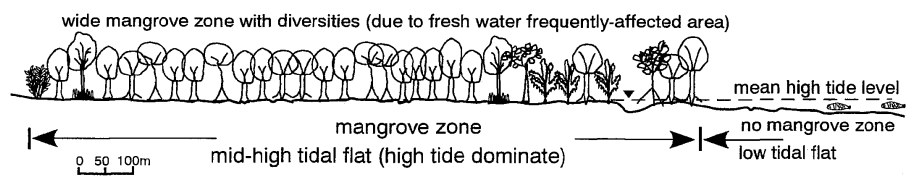

Legend

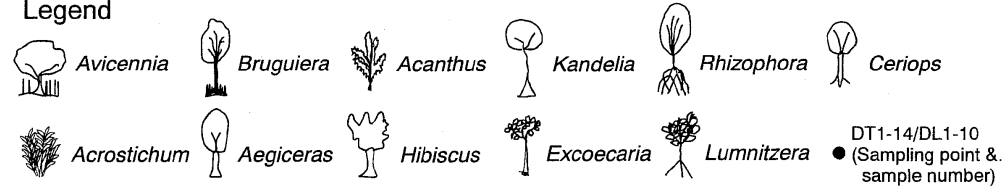

Fig. 4 Transects 1-4 (unscaled vertically) show mangrove zonation over intertidal zone in Dongzhai mangrove swamp

Samples DT1-14 and DL1-10 collected from seaward to landward for pollen analysis. 
These zones are normally perpendicular to the coastline or river. Our extensive field observations for the six transects (Figs. 4 and 5) indicate that the mangroves accreting on shores within the study area consist of successional communities. Kandelia can tolerate a lower salinity environment but wider temperature range than other mangroves, and it often favors river sides to grow (Fig. 2-A). Sonneratia and Avicennia are pioneering genera which initially grow on intertidal mudflats (Fig. 2-B, C). As the sediment becomes stabilized, other genera such as Rhizophora and Bruguiera successively follow these pioneering genera (Fig. 2-D). Nypa palm (Fig. 2-E) and Xylocarpus (a rare genus and key protected mangrove plants in Hainan Island) are found in the areas that are subject to only a few tidal washes each month. We observed that diversified mangroves tend to develop along riverine sides where frequent fresh water brings in the large amount of fine sediments containing rich nutrients (Fig. 2-F). Detailed mangrove zonation patterns over intertidal zones are shown in six transects $(1-6)$, illustrated by Figures 4 and 5 .

\section{Surface pollen assemblages}

Our pollen work revealed more than 45 main pollen types, displayed by groups for mangroves and associates, the other trees and shrubs, herbs, aquatics, fern spores, fungal spores and indeterminate. The percentages of the selected mangroves, the other frequent pollen and spores are shown in Figures 6 and 7 . Counts for the pollen types are expressed as percentages based on the total pollen excluding fern spores, aquatics and indeterminate; counts for fern spores are expressed as percentages based on the total pollen plus spores. Surface pollen spectra for the two mangrove swamps in this study show no significant difference excluding transect 5 . A slightly high pollen percentage of trees and shrubs other than mangroves, probably transported by river from terrestrials, is also visible (Figs. 6 and 7). The pollen diagrams also showed continuous high values for pollen concentration, around 3,000 5,000 grains/g of dry sediments.

1) Transect 1 (Cangtou, the Dongzhai swamp ;
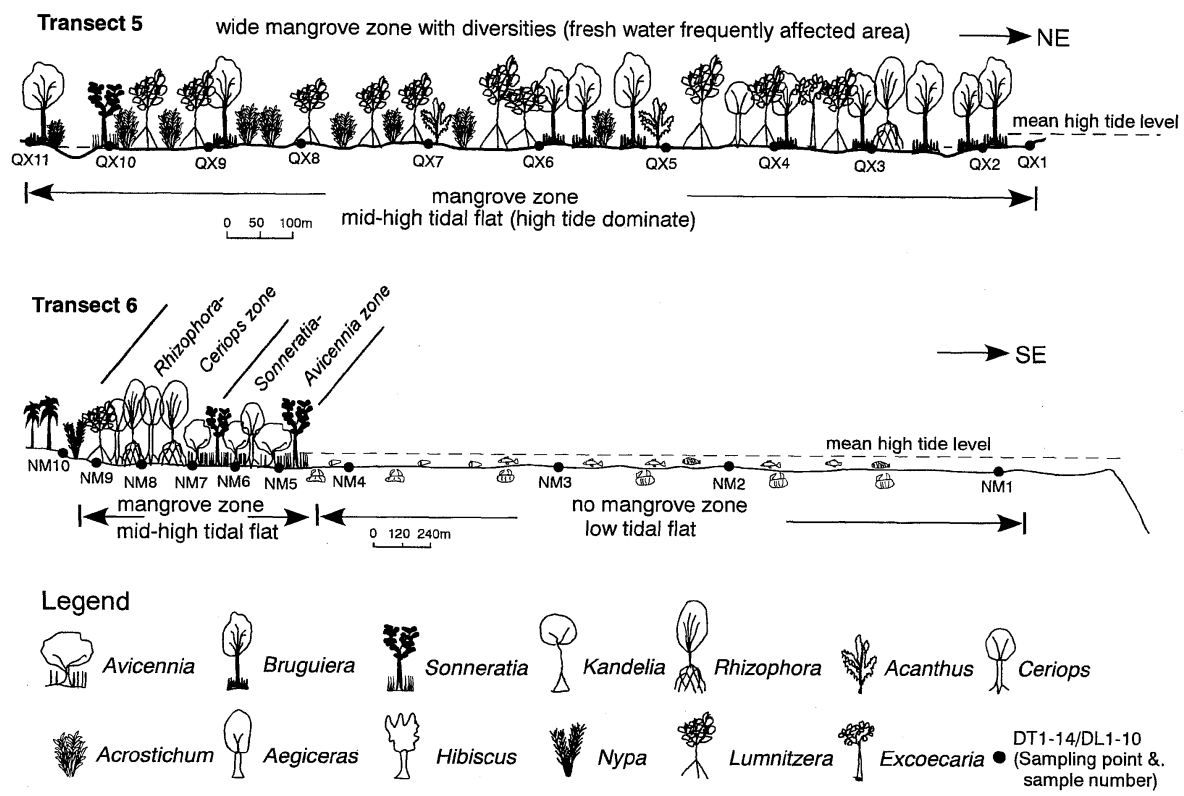

Fig. 5 Transects 5 and 6 (unscaled vertically) show mangrove zonation over intertidal zones in Qinglan mangrove swamp

Samples NM1-10 collected from seaward to landward, QX1-10 collected across the Wenchang delta for pollen analysis. 
pollen zones DT-1, DT-2 and DT-3)

This transect spanned about $2 \mathrm{~km}$ seaward to landward, but with the slight slope towards seaward. The pollen diagram showed distinct variation. Rhizophoraceae and Avicennia showed higher percentages in the pollen assemblages for zone DT-2. Whereas the other pollen taxa showed relatively higher percentages for these types in zone DT-1 and zone DT-3 (Fig. 6).

Zone DT -1 showed high pollen percentages $(62-67 \%)$ for mangrove and associate types in low tidal flats, where regional pollen deposits (e.g. Fagaceae) were also abundant. Aquatic and herb pollen had higher percentages than these abundances for zone DT-2.

Zone DT -2 was distinctive compared to zone DT -1 and zone DT -3 , and was characterized by high percentages of Rhizophora and Avicennia pollen. These types were $60-65 \%$ of the total pollen sum, and the sum of the pollen for mangrove and associates was $73-84 \%$ of the total pollen. Ceriops pollen also occurred in a relatively high percentage in this Ceriopsdominated site. A marked increase and decrease of pollen percentages in pollen diagram was Avicennia. These abundances fluctuate because sampling sites occurred along tide channels, and Avicennia is apt to grow in places with a high frequency of tidal inundation. Fewer aquatic and herb were present in the pollen diagram for this zone.

Zone DT-3 is characterized by a slightly lower mangrove pollen percentage $(64-69 \%)$ than the previous zone, and showed nearly equal abundance as zone DT-1. Landward species, such as Hibiscus, Clerodendron, Scyphiphora and Pandanus, take the place of mangrove species, and pollen from the terrestrial hinterlands was also present in a relative high percentage $(20-25 \%)$. Aquatic and herb pollen showed a slightly higher percentage than those for zone DT-2.

2) Transect 3 (Bodu, the Dongzhai swamp; pollen zones DL-1, DL-2 and DL-3)

This transect extended ca. $1 \mathrm{~km}$ seaward to landward. And the pollen diagram reflects vegetation zones along the transect, e.g. pollen from surface samples reflect the source plants effectively (Fig. 6).
Zone $\mathrm{DL}^{-1}$ is the lowest zone seaward and consisted of abundant pollen generated from local and regional vegetation. Around 60-65\% mangrove and associates pollen were present. The regional pollen components were abundant compared with zone DL-2 in the midhigh tidal flat. Aquatic and herb pollen showed slightly higher percentages than those in zone DL-2, and were similar to zone DL-3.

Zone DL-2 was characterized by a maximum for Rhizophoraceae $(63 \%)$ in the mid-tidal flat, where Rhizophora dominates the mangrove communities. This zone showed an increase for mangrove and associate pollen percentages (75-82\%), mainly from Rhizophora, Avicennia, Ceriops and Bruguiera. Very few aquatics, herbs and ferns were present in this zone.

Zone DL-3 had a lower percentage $(60-62 \%)$ of mangrove and associate pollen compared to zone DZ-2. Mangrove associates pollen showed higher percentages. Other tree taxa, shrubs and herbs were $30-35 \%$ of total pollen. These types, such as Palmae, Fagaceae, Euphorbiaceae, Pandanus, Casuarina and Poaceae, probably generated from landward and regional vegetation. Aquatic and herb pollen showed slightly higher percentages than those in zone DL-2, and are similar to zone DL- 1 .

3) Transect 5 (Xiachang, the Qinglan swamp; pollen zones $\mathrm{QX}-1, \mathrm{QX}-2$ and $\mathrm{QX}-3$ )

This transect (ca. $1.8 \mathrm{~km}$ wide) was situated in the upper-stream part of Wenchang delta and showed higher mangrove diversity (Fig. 1). The Wenchang River likely brings in large amounts of erosional sediments that spread over the delta and become trapped by network of prop roots and pneumatophore of mangroves. Therefore, the pollen assemblages were a mixture of autochthonous and allochthonous pollen. Nevertheless, pollen percentages of mangrove and associates were still relatively higher than those for the pollen of other threes and shrubs. In the central transect, mangrove and associates pollen showed higher percentages than those on landward sides (Fig. 7).

Zone QX-1 was characterized by high pollen percentages of mangrove and associates (62$71 \%)$. Other tree and shrub pollen had moderately high pollen percentage $(29-38 \%)$. Fern 


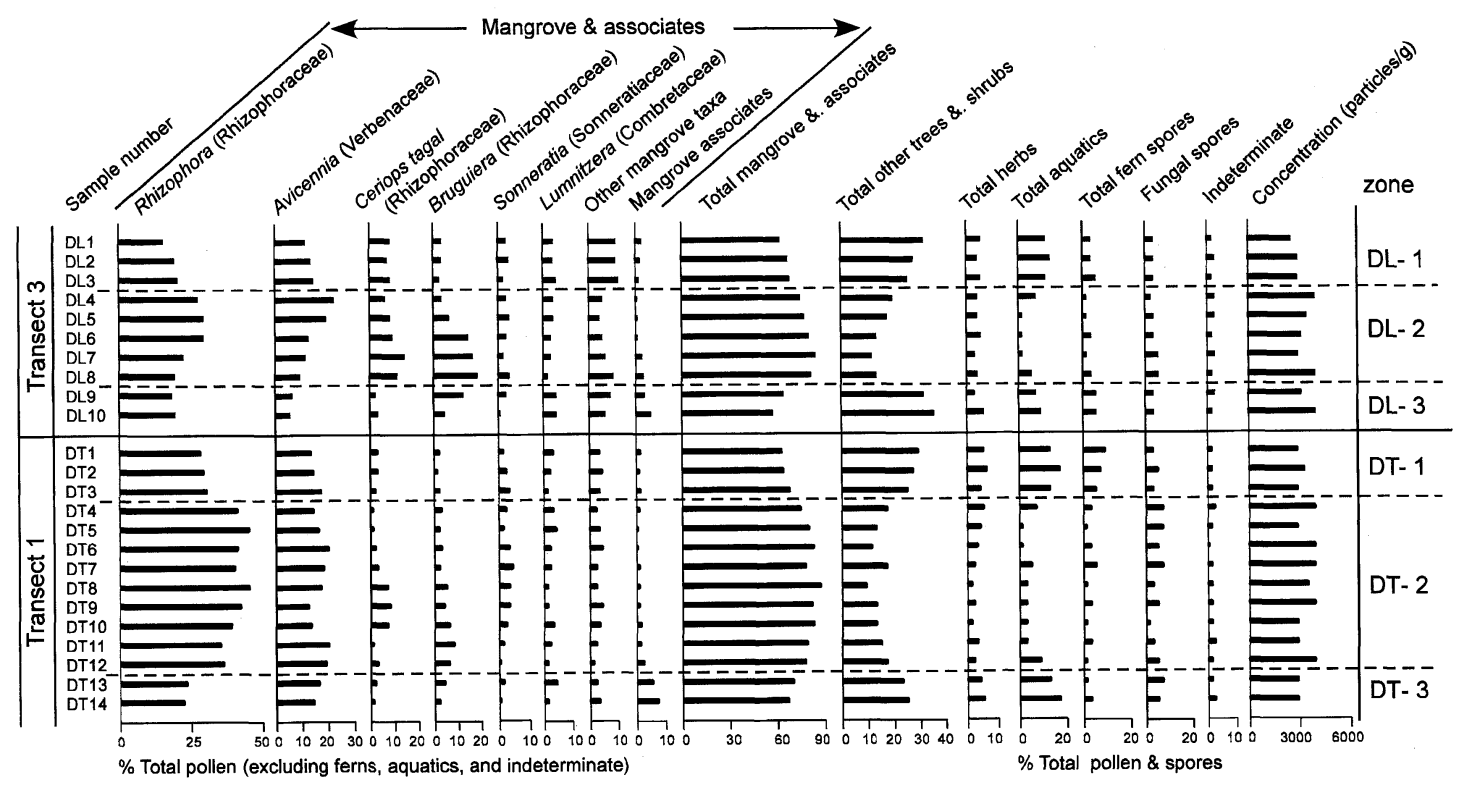

Fig. 6 Percentage summary pollen diagram for transects 1 and 3, showing vegetation groups, percentages of the most frequent mangrove pollen taxa, and pollen concentration (horizontal solid lines separate transects (see column to left) ; dash lines separate pollen zones)

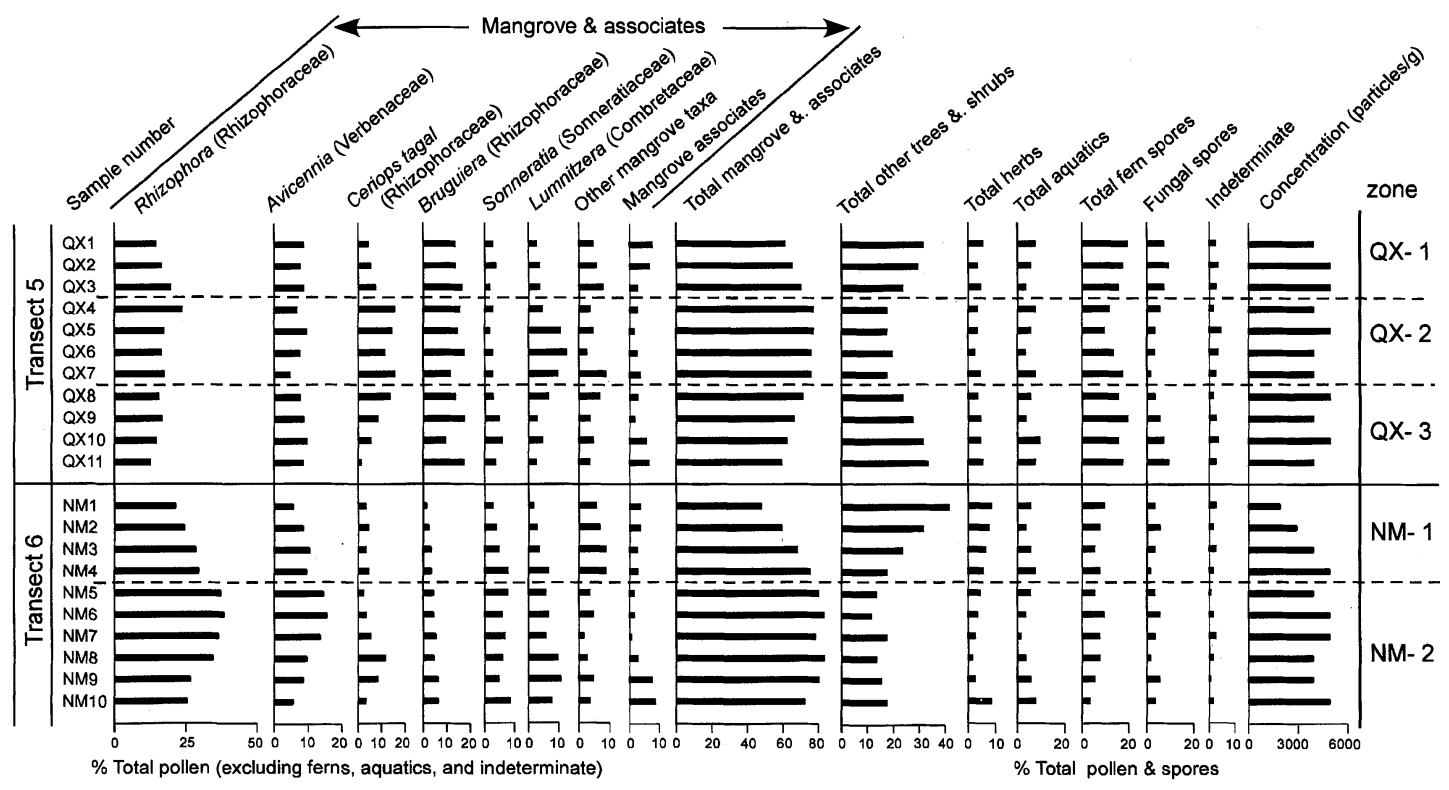

Fig. 7 Percentage summary pollen diagram for transects 5 and 6 , showing vegetation groups, percentages of the most frequent mangrove pollen taxa, and pollen concentration (horizontal solid lines separate transects (see column to left); dash lines separate pollen zones)

and fungal spores were a slightly higher than the values for zone $\mathrm{QX}-2$, but were similar to those for zone QX-3. Rhizophora pollen provided low pollen percentages, probably due to lower salinity along QX-1.

Zone QX-2 was dominated by high pollen percentages of mangrove and associates (7778\%), while other tree and shrub pollen 
showed decreasing pollen percentages (2223\%). Pollen percentages for Lumnitzera showed a slight increase (samples QX4, QX5, QX6 and QX7). However, its pollen values were considering these samples were collected beneath a Lumnitzera dominated zone. Ceriops pollen showed an increased percentage to a maximum of $16 \%$.

Zone QX-3 featured an increase in pollen percentages for trees and shrubs (excluding mangrove and associates) similar to zone QX -1 . Mangrove pollen showed a slight decrease in this zone, with accompanying decreased percentages for Ceriops pollen, and increased percentages for Lumnitzera pollen and fern spores.

4) Transect 6 (Maibang, the Qinglan swamp; pollen zones NM-1 and NM-2)

This transect was ca. $3 \mathrm{~km}$ wide and located on the open seashore of Maibang, southern Qinglan. The transect bounded rich littoral inhabitants (coral, crab and mollusk) of the low tidal flat (Fig. 5), and mangroves grew parallel to the coastline. The narrow tidal range caused less diversity, e.g., wider lower tidal flat with no mangrove vegetation gave way to mollusks and corals. Two pollen zones (zone NM-1 and zone NM-2) were recognized (Fig. 7).

Zone NM-1 was characterized by nearly equal pollen percentages for mangrove and other threes and shrubs. Total mangrove and associates pollen showed slightly higher than other trees and shrubs (Fagaceae, Palmae and Poaceae : 33\%). Pollen percentages for other trees and shrubs in three samples (NM1, NM2 and NM3) from the lower tidal flat showed higher values than samples NM4 and NM5. Pollen concentration for this zone was lower than that for zone NM-2, probably due to the influence of stronger tides.

Zone NM-2 was dominated by higher mangrove pollen percentages compared to zone NM-1. Rhizophora, Avicennia and Sonneratia had high pollen percentages in the seaward sites, whereas Ceriops replaces Rhizophora, Sonneratia and Avicennia in the landward sites. Lumnitzera and Bruguiera showed increased pollen percentages in the landward sites. Higher percentages of terrestrial pollen (represented by other tree and shrub pollen, Fig. 7) were characteristic of the landward zone (samples NM9 and NM10). Mangrove pollen showed a slight decrease in percentages in the transition zone. Principal components of other tree and shrub pollen were Fagaceae, Euphorbaceae and Casuarina.

\section{Discussion}

\section{Mangrove sediments}

In mangrove swamps, vertical accretion is a mixture of clastic sediments and organic materials produced by the mangroves and their associated fauna (Bird, 1972). The accumulation of the sediments occurs at the slack of high-tide and during storm surges as well as after floods, bringing in materials from the sea or rivers during flood stages (Carlton, 1974). Sedimentation in mangrove swamps is generally controlled by local hydrological and geomorphological factors. Data, however, for the rate of sediment accretion beneath mangrove swamps are scarce. Our future work, using radiocarbon dating of sediment cores within the present study area, will provide estimation for average accumulation rate of sediments.

Floating organic debris are trapped in the prop roots and pneumatophores of the mangroves and together with the products of in situ organic decomposition, combining with the silty sediments to form the so-called mangrove muds or mucks (Macnae, 1968). The organic litter of the swamps may form a superficial peat deposit. The development of such peat, collected in shallow sediment cores for mangrove swamps in Hainan Island, has been described by Sang et al. (1993). In addition, fossil pollen from the peats found in mangrove swamps of Hainan Island were analyzed by Zhang et al. (1999). They discussed the history of mangrove vegetation development based on their pollen results.

Mangrove mud, with a sandy layer often underlying at the bottom of the mud, is a recognizable mangrove swamp deposit, and is considered to be a sedimentary unit. The development of networks of trunks, prop roots and pneumatophores benefits from those trapped sediments with high nutrients. Most sedimentation in mangrove swamps results from the reduction in current velocity and 
attenuation of wave in the dense vegetation. Pieter (1995) suggested that mangroves with pneumatophores were better sediment traps than the mangrove with prop roots. Our work indicates that pollen deposition in mangrove swamps is a direct result of proximity to source plants, which includes both mangrove and adjacent non-mangrove flora. Pollen grains found in this study were derived from various taxonomic groups. We note that the mangrove swamps received a pollen supply from three likely sources : 1) local mangrove pollen deposit, 2) regional pollen by wind and water and 3) reworked pollen by tide current. Furthermore most of the environmental zones in the coastal areas are associated with significant pollen zonation. This study of surface pollen deposition is relevant for future interpretations of mangrove pollen records and for the recognition of ancient shorelines and the paleogeography of coastal areas as defined by mangrove pollen zonation.

\section{Mangrove pollen representation}

As we have shown, the pollen of Rhizophoraceae is strongly represented in mangrove surface samples and the pollen of this group contains at least three major mangrove genera that exhibit a variety of ecological tolerances (Caratini et al., 1973; Woodroffe et al., 1985). The Rhizophoraceae are also a widely distributed taxon with at least six species in the western Pacific region. Rhizophoraceae tend to grow near the seaward or deep water limit of mangrove habitat, often occurring behind a zone of Sonneratia and/or Avicennia. Although studies have shown how different species of Rhizophora produce prodigious quantities of pollen that disperse over long distances, Caratini et al. (1973) showed strongly localized deposition for this pollen type. This was also supported by John (1985), who recorded consistently high values for Rhizophora pollen in sediment samples collected beneath Rhizophora-dominated forest. The similar results from our transects 1 and 3 show that Rhizophora pollen overshadows, to some extent, pollen representation of other species in nonRhizophora dominated mangroves, e.g. transect 6 from the Qinglan mangrove swamp.

The genus Bruguiera contains a number of species of trees and shrubs that shows a preference for areas with significant tidal flushing and moderate soil salinities, and often grows in association with Rhizophora. The genus Ceriops is a more commonly landward mangrove type, and on drier coasts, it survives on the areas with high soil salinities that are infrequently inundated and poorly drained. We found Ceriops dominating the higher tidal flats in large areas of the Dongzhai mangrove swamp. Although there is evidence that species within both of these genera may be entomophilous (Tomlinson et al., 1979), they produce considerable quantities of pollen that may retain highly localized distribution within intertidal sediments, despite the potential for redistribution (John, 1985).

The pantropical genus Avicennia contains a number of species that displays a wide habitat range within mangrove environments. $A$. marina pollen is often recorded at low but consistent frequencies (Woodroffe et al., 1985). Pollen percentages of $A$. marina are generally moderate, even in samples from A. marina dominated stands, e.g. transects 1 and 3 . We conclude that Avicennia pollen shows relatively strongly and highly localized representation, making it a useful environmental indicator.

Sonneratia pollen is consistently recorded at low frequencies in surface sediments. However, these low representations are influenced by the abundance of Rhizophora pollen from nearby sources, as shown in transect 6 , where Rhizophora pollen values are consistently high. Wang and Zhang (1998) found Sonneratia pollen in early Quaternary deposits in Leizhou Peninsula, to the north of Hainan Island. Zheng (1995, 2000) also reported Sonneratia pollen from Chao-shan plain, southeastern China. In both cases, warmer climate than the present was inferred since modern distributions of Sonneratia only occur on Hainan Island.

The genus Lumnitzera exists throughout the tropical west Pacific. Evidence from Pichavaram and northeastern Australia indicates that L. littorea and L. racemosa maintain low pollen representation in surface sediments that is equivalent to the relative scarceness of parent plants (Caratini et al., 1973 ; John, 1985). 
In this study, Lumnitzera pollen shows occasional occurrence with moderate percentages in Lumnitzera-dominated communities. Generally, this species has low pollen production.

The mangrove palm Nypa fruticans is common in humid areas of the tropical west Pacific region (Fig. 2-E). Muller (1959) found this pollen type regularly in mangrove sediments, and concluded that although the flowers of Nypa produce abundant pollen, Nypa vegetation as a whole does not deposit very much pollen in sediments. In this study, Nypa is not well developed in the mangrove swamps, and therefore its pollen values are low. A further work concerning Nypa pollen production is necessary to determine whether this type is a useful environmental indicator.

The only ferns commonly recorded in mangrove habitats are from the genus Acrostichum, which includes at least two mangrove species. In humid areas, these ferns grow as understory in mangrove forests, where tidal inundation is infrequent and fresh ground water seepage is persistent. Anderson and Muller (1975) found relatively high percentages of Acrostichum spores in mangrove sediments, and concluded that these spores were a useful indicator for mangrove environment. However, our study shows low values for this spore.

Evidence from this study also indicates that other common mangrove types are poorly represented by their pollen in sediments. These include Excoecaria, Aegiceras, Kandelia and Xylocarpus, found in transects 3 and 5 . However, these taxa rarely dominate mangrove vegetation.

3. Relationship between modern pollen and vegetation in mangrove swamps

Based on the observation of six transects for modern mangrove zonation and the pollen analysis from our selected transects, we have established a relationship between surface pollen and local vegetation. Our results from two mangrove swamps show that mangrove pollen distribution is in accordance with their parent plant zonation. These results also show that the surface pollen spectra for the four transects are generally similar. Our only exception is from transect 5 in the Qinglan mangrove swamp, which was slightly different due to the pollen influx from the Wenchang River. Our work also shows that non-mangrove tree and shrub pollen, mainly from regional taxa such as Fagaceae, Euphorbiaceae and others are well-represented (Fig. 7). These pollen grains are probably brought in by river discharge and air streams. In the Dongzhai mangrove swamp, mangrove pollen from transects 1 and 3 was very abundant, especially the genera Rhizophora, Avicennia, Ceriops and Bruguiera. However, Bruguiera and Ceriops were less abundant than Rhizophora and Avicennia in transect 1 . In the central transects, mangrove and associates pollen dominates, indicating autochthonous pollen deposition within mangrove swamps. Non-mangrove pollen components are less evident than mangrove types, and this results also indicate that mangrove pollen is a reliable proxy. Likewise, surface pollen spectra for transects 5 and 6 from Qinglan mangrove swamp showed similar results, particularly in the central parts of intertidal zones. In general, most tropical vegetation is not effectively reflected by their pollen, largely due to low pollen production, poor preservation, or unfavorable pollination mechanisms. This is not the case for mangrove vegetation, which was clearly reflected in the surface pollen records within mangrove swamps. Some mangroves have low pollen production, such as Excoecaria, Kandelia, Aegiceras and Xylocarpus. Rhizophora which dominates the pollen spectra is a wind-pollinated genus, hence its pollen is over-represented in the surface sediments of transect 6 (Figs. 4 and 7). The Rhizophora pollen was also found in samples collected along intertidal flats where Rhizophora does not usually grow. The entomophilous genera Ceriops, Bruguiera and Lumnitzera show moderate to low pollen representation in the sediments, as shown in Bruguiera and/or Lumnitzera dominated mangrove communities in the mid parts of transects 5 and 3 .

Behling et al. (2001) provided estimates of mangrove pollen representation for Avicennia and Ceriops, in their study of Holocene mangrove ecosystem dynamics for the Braganca Peninsula, northeastern Para, Brazil. In their study, the relationship between pollen and 
local mangroves is strongly linked based on modern pollen rain (1.5 years) within mangroves. John and Sally (2001) also carried out an extensive pollen analysis for surface samples from Costa Rica and showed a similar close linkage between pollen and mangrove plant sources.

\section{Conclusions}

The results of surface pollen spectra obtained from mangrove swamps generally show a close linkage between pollen and local vegetation, and provide a basis for interpreting mangrove paleoecology for stratigraphic samples from the same sites. Mangrove zonation is manifested in the pollen spectra by the seaward pioneer genera Avicennia and Sonneratia, followed by Rhizophora and Ceriops in mid-high tidal flats, then the landward genera Bruguiera and Lumnitzera, then by Nypa and Xylocarpus in the higher tidal zone and then finally by mangrove associates adjacent to terrestrial vegetation. The results of pollen analyses from two coastal mangrove swamps are consistent with plant sources, roughly arranged in a zonal pattern along intertidal flats. Some mangrove pollen taxa, particularly Rhizophora, Avicennia, Ceriops and Bruguiera, are well-represented in the surface sediments. Our results are also consistent with previous studies showing that other common mangrove types including Excoecaria, Kandelia, Aegiceras and Xylocarpus are poorly represented by their pollen in the surface sediments. However, these taxa rarely dominate mangrove communities.

Pollen production of mangroves varies from genus to genus because of different biologies. So pollen representation should be considered when interpreting mangrove pollen data. Rhizophora is wind-pollinated, and its pollen is over-represented even where Rhizophora plants are not dominant along intertidal zones. The entomophilous genera Ceriops, Bruguiera and Lumnitzera show moderate to low pollen representation in the sediments from some transects where these are dominant. Occasionally rare exotic palynomorphs also occur in most samples, however, the dominant pollen is from local mangrove vegetation. These results pro- vide a useful basis for interpreting the paleoecology for mangrove swamps. The present study is a crucial component for understanding and interpreting paleoecology and paleoenvironment of tropical marshes in Hainan Island. Limitations for interpreting mangrove pollen data come from factors that affect pollen deposition and dispersal, such as mangrove pollen production/representation, bio-turbulence and potentially reworked sediments by tidal currents. However our results are robust enough to continue to do evaluation of mangrove pollen deposition and dispersal in tropical areas.

\section{Acknowledgements}

We gratefully acknowledge the cooperation of Mr. Chen Jianhai from National Nature Reserve of Mangroves in Hainan Island, who provided us access to sampling and invaluable field assistance. Special thanks go to Dr. Okuda Masaaki and Prof. Kuroda Tomio for reviewing this paper. We deeply appreciate their suggestions and critical comments. Our grateful thanks are due to Prof. Paige Newby and Dr. Zhen Zhou from Brown University, US, for helping improve English manuscript and constructive suggestions. The first author is grateful of Miss Hongo Misao for her help with Japanese abstract. Prof. Kumai Hisao, Yoshikawa Shusaku and Associate Prof. Mitamura Muneki are thanked for their suggestions and encouragements for this study. The present study was also partially supported by Natural Science Foundation of China.

\section{References}

Anderson, J.A.R. and Muller, J. (1975) Palynological study of a Holocene peat and a Miocene coal deposit from NW Borneo. Rev. Palaeobot. Palynol., 19, 291-351.

Behling, H. and Marcondes, L.D.C. (2001) Holocene vegetational and coastal environmental changes from the Lago Crispim record in northeastern Para State, eastern Amazonia. Rev. Palaeobot. Palynol., 114, 145-155.

Behling, H., Cohen, M.C.L. and Lara, R.J. (2001) Studies on Holocene mangrove ecosystem dynamics of the Braganca Peninsula in northeastern Pará, Brazil. Palaeogeogr., Palaeoclimatol., Palaeoecol., 167, 225-242.

Bird, E.C.F. (1972) Mangroves and coastal morpholo- 
gy in Cairns Bay, North Queensland. Jour. Trop. Geo., 35, 11-16.

Blasco, F., Saenger, P. and Janodet, E. (1996) Mangroves as indicators of coastal change. Catena, 27, 167-178.

Caratini, C., Blasco, F. and Thanikaimoni, G. (1973) Relationship between the pollen spectra and vegetation of a south Indian mangrove. Pollen Spores, 15 (5), 281-292.

Carlton, J.M. (1974) Land-buildings and stabilization by mangroves. Environ. Conser., 1, 285-294.

David, T., Yen, H.O., Peta, G. S. and John, D. (2001) Late Quaternary peat formation and vegetation dynamics in a lowland tropical swamp ; Nee Soon, Singapore.Palaeogeogr., Palaeoclimatol., Palaeoecol., 171, 269-287.

Editorial Board of China Vegetation (1995) The vegetation of China. 1382 p, Science Press, Beijing. (C)

Faegri, K. and Iversen, J. (1989) Textbook of pollen analysis (the 4th edition). $328 \mathrm{p}$, Wiley, Chichester.

Guangdong Institute of Botany (1976) Guangdong vegetation. 158 p, Science Press, Beijing. (C)

Hainan Geological Institute (1992) Geology of Hainan Island. $76 \mathrm{p}$, Hainan Science Press, Hainan Island. (C)

Islam, S.M. and Tooley, M. J. (1999) Coastal and sealevel changes during the Holocene in Bangadesh. Quat. Int., 55, 61-75

Joanna, C.E. (1989) Pollen analysis of mangrove sediments as a sea-level indicator: assessment from Tongatapu. Palaeogeogr., Palaeoclimatol., Palaeoecol., 74, 327-341.

Joanna, C.E. (1996) Pollen evidence of Late Holocene mangrove development in Bermuda. Glob. Eco. Biogeo. Lett., 5, 315-326.

John, G. (1985) The palynology of mangroves on a prograded shore, Princess Charlotte Bay, North Queensland, Australia. J. Biogeogr., 12, 323-348.

John, C.R.III and Sally, P.H. (2001) Modern pollen spectra from Costa Rica. Palaeogeogr., Palaeoclimatol., Palaeoecol., 124, 53-71.

Li, M.S. and Lee, S.Y. (1996) Mangroves of China : a brief review. Fore. Eco. and Mana., 96, 241-259.

Lin, P. (1999) Mangrove ecosystem in China. 271 p, Science press, Beijing.

Lin, P. (2001) A review on the mangrove research in China. Jour. Xiamen Univ. (Natural Science), 40 (2), 592-603. $(\mathrm{C}+\mathrm{E})$

Liu, L.F. and Tang, S.Q. (1989) Pollen morphology of the mangrove plants in China. Guihaia, 9 (3), 221232. $(\mathrm{C}+\mathrm{E})$

Macnae, W. (1968) A general account of the fauna and flora of mangrove swamps and forests in the Indowest-Pacific region. Advan. Mar. Bio., 6, 73-270.

Muller, J. (1959) Palynology of recent Orinoco delta and shelf sediments. Micropaleontology, 1, 1-32.

Muller, J. (1969) A palynological study of the genus Sonneratia (Sonneratiaceae). Pollen spores, 11 (2), 223-298.
Muller, J. (1978) New observations on pollen morphology and fossil distribution of the genus Sonneratia (Sonneratiaceae). Rev. Palaeobot. Palynol., 26, 277300.

Muller, J. and Caratini, C. (1977) Pollen of Rhizophora (Rhizophoiraceae) as a guide fossil. Pollen spores, 19, 361-389.

Peter, K., Eric, B. and Sana, S. (1985) Man in the Mangroves. $54 \mathrm{p}$, United Nations University.

Pieter, G.E.F.A. (1995) Geomorphology and sedimentology of mangroves. Perillo, G.M.E. (ed.) Geomorphology and sedimentology of estuaries : $333^{-}$ 357, Elsevier.

Sander, V.D.K. (2001) Pollen distribution in marine sediments from the south-eastern Indonesian waters. Palaeogeogr., Palaeoclimatol., Palaeoecol., 171, 341-361.

Sander, V.D.K., Dan, P., John, T., Jennie, F., Rien, A.C. D. and Papay, S. (2001) Late Quaternary palaeoecology, palynology and palaeolimnology of a tropical lowland swamp : Rawa Danau, West-Java, Indonesia. Palaeogeogr., Palaeoclimatol., Palaeoecol., 171, 185-212.

Sang, S.X, Liu, H.J. and Shi, J. (1993) A study of the transgressive genesis on the Hainan mangrove peats and its significance. Mar. Geo. \& Quat. Geo., 13 (4), 57-64. (C+E)

Sun, X.J. and Li, X. (1999) A pollen record of the last $37 \mathrm{ka}$ in deep sea core 17940 from the northern slope of the South China Sea. Mar. Geo., 156, 227244.

Sun, X. J., Li, X. and Beug, H. J. (1999) Pollen distribution in hemipelagic surface sediments of the South China Sea and its relation to modern vegetation distribution. Mar. Geo., 156, 211-226.

Tomlinson, P.B. (1986) The botany of mangroves. 418 p, Cambridge University Press.

Tomlinson, P.B., Primack, R.B. and Bunt, J.S. (1979) Preliminary observation on the floral biology in mangrove Rhizophoraceae. Biotropica, 11 (4), 256277.

Velez, M.I., Wille, M., Hooghiemstra, H., Metcalfe, S., Vandenberghe, J. and Borg, van der K. (2001) Late Holocene environmental history of southern Chocó region Pacific Colombia ; sediment, diatom and pollen analysis of core El Caimito. Palaeogeogr., Palaeoclimatol., Palaeoecol., 173, 197-214.

Wang, F.X., Chen, N.F., Zhang, Y.L. and Yang, H.Q. (1995) Pollen flora of China. 2nd Edition, $461 \mathrm{p}$, Science Press, Beijing. (C)

Wang, K.F., Zhang, Y.L. and Wang, Y.J. (1975) Studies on mangrove pollen morphology and its application in marine geology. Chin. Sci. Bul., 11, 518-524. (C)

Wang, K.F., Sun, Y.H., Zhang,Y.L., Jiang, H. and Zhang, Y.C. (1997) The spore-pollen and algal assemblages in the sediments of East China Sea. $76 \mathrm{p}$, China Ocean Press.

Wang, K.F. and Zhang, Y.L. (1998) Mangrove pollen 
records from Zhanjiang Formation in Leizhou Peninsula and its geological significance. Acta Ocean. Sinica, 20 (4), 141-145. (C+E)

Wang, K.F., Zhang, Y.L. and Mao, L.M. (1998) Mangrove pollen record and its application in paleoenvironmental reconstruction in China. The $a b$ stract album of annual Quaternary conference of China, 102-103. (C)

Willard, D.A., Weimer, L.M. and Riegel, W.L. (2001) Pollen assemblages as paleoenvironmental proxies in the Florida Everglades. Rev. Palaeobot. Palynol., 113 (4), 213-235.

Woodroffe, C.D., Thom, B.G. and Chappell, J. (1985) Development of widespread mangrove swamps in mid-Holocene times in northern Australia. Nature, 317, 711-13.

Woodroffe, C.D. and John, G. (1991) Mangrove biogeography : the role of Quaternary environmental and sea-level change. J. Biogeogr., 18, 479-492.

Wu, J.H. and Zhang, S. (1988) Physical geography of China. 194 p, High Education Press, Beijing. (C)

Zhang, Y.L., Wang, K.F., Li, Z. and Liu, L.F. (1997 a) Studies on pollen morphology of Sonneratia genus in China and its paleoecological environmental significance. Mar. Geo. \& Quat. Geo., 17 (2), 47-52.(C+E)
Zhang, Y.L., Wang, K.F., Li, Z. and Liu, L.F. (1997 b) A study on pollen morphology of Rhizophoraceae in China and its palaeoenvironmental implication. Mar. Sci. Bul., 16 (6), 31-38. (C+E)

Zhang, Y.L., Zhang, W.D., Li, Z., Mao, L.M. (1999) Evolution of mangrove forests in northeastern Hainan Island since mid-Holocene. Mar. Sci. Bul., 18 (2), 5257. $(\mathrm{C}+\mathrm{E})$

Zheng, Z. (1991) Pollen flora and paleoclimate of the Chao-Shan plain during the last 50,000 years. Acta Micropalaeo. Sinica, 8 (4), 461-480. (C+E)

Zheng, Z. (1995) Distribution of Sonneratia in the southeastern China during the late Quaternary. The Journ. Sun. Univer., 4, 81-90. (C+E)

Zheng, Z. (2000) Late Quaternary vegetational and climatic changes in the tropical and subtropical areas of China. Acta Micropalaeo. Sinica, 17 (2), 125146. $(\mathrm{C}+\mathrm{E})$

Zheng, Z. and Li, Q.Y. (2000) Vegetation, climate and sea level in the past 55,000 years, Hanjiang Delta, southeastern China. Quat. Res., 53,330-340.

(C) in Chinese, $(\mathrm{C}+\mathrm{E})$ in Chinese with English abstract. 


\title{
中国海南島北部の海岸マングローブ潟における花粉学的研究 一表層花粉組成と現生マングローブ植生との関係一
}

\author{
毛 礼米*1・王 開発*2 ・ 毕 華*3
}

\section{〔要旨〕}

中国海南島北部に位置する東寨（Dongzhai）と清瀾 (Qinglan) に分布する海岸マングローブ潟の表層から 採取した堆積物を花粉分析し，完新世におけるマング ローブの变遷史を復元するための基礎資料を得たので報 告する.

これらの地域のマングローブが繁茂する潮間帯に, 陸 域から沖合に向けて 6 測線 (Transects 1-6) の地形と植 生の断面を作成し, この場所におけるマングローブの種 構成による分帯を試みた。さらに, このうち 4 测線 （Transects 1, 3, 5, 6) について表層堆積物中の花粉分析 を行った．その結果から，表層花粉組成と現生マング ローブの構成種の関係を考察した. 潮間帯におけるマン グローブ内の堆積環境とマングローブ種ならびに付随す る構成種の分帯の関係を特徵づけるために，表層試料か
ら得たすべてのパリノモルフを同定，集計した．その中 には花粉はもちろん，羊歯胞子や識別不能の有機物（お そらくマングローブの生産物) が含まれていた. 特に Rhizophora, Avicennia, Ceriops, Bruguiera は高率であ り, Excoecaria, Aegiceras, Kandelia, Xylocarpus は低 率であることから，卓越する花粉組成は現地性のマング ローブやそれに付随する植生からのあのであり, 後背地 の植生からのあのをわずかにとあなうと判断される. 測 線を通じて, 現生の分帯によく似た帯状配列の傾向が読 みとれる.したがって，表層の花粉組成はごく限られた 範囲のマングローブの影響が強く反映されているものと 考えられる. これらのことに加えて，マングローブを構 成する種ごとの花粉の出現率を变化させうる要因につい てあ議論した.

*1 大阪市立大学大学院理学研究科 $=$ 558-8585 大阪市住吉区杉本 3-3-138. E-mail

*2 中国上海市同済大学海洋地質 ·地球物理系

*3 中国海南省海口市海南師範大学地理系 